\title{
Crime and Punishment in Early Modern Russia
}

\author{
Michael Khodarkovsky \\ Loyola University Chicago, mkhodar@luc.edu
}

Follow this and additional works at: https://ecommons.luc.edu/history_facpubs

Part of the History Commons

\section{Author Manuscript}

This is a pre-publication author manuscript of the final, published article.

\section{Recommended Citation}

Khodarkovsky, Michael. Crime and Punishment in Early Modern Russia. Social History, 38, 4: , 2013.

Retrieved from Loyola eCommons, History: Faculty Publications and Other Works, http://dx.doi.org/

10.1080/03071022.2013.842770

This Book Review is brought to you for free and open access by the Faculty Publications and Other Works by Department at Loyola eCommons. It has been accepted for inclusion in History: Faculty Publications and Other Works by an authorized administrator of Loyola eCommons. For more information, please contact ecommons@luc.edu.

\section{c) (†) $\ominus$}

This work is licensed under a Creative Commons Attribution-Noncommercial-No Derivative Works 3.0 License. (c) Routledge, 2013. 
Nancy Kollmann, Crime and Punishment in Early Modern Russia (Cambridge, 2012)

This new magisterial study comes from the pen of the most seasoned scholar, who devoted her entire academic career to studying the social and legal landscape of the early modern Russia. In her two previous books, Nancy Kollmann showed the importance of such traditional institutions as kinship (Kinship and Politics, 1987) and precedence and honor (By Honor Bound, 1999) in holding the Muscovite society together. The new book is a comprehensive study of the criminal law and its practice in early modern Russia.

Kollmann's stated goal is to break the binary opposition between the West and Russia and to show that Russian system of justice was in line with the developments in the West European monarchies. To do so, Kollmann examines a large collection of archival sources from Russia's different regions and compares Russia with Europe, mostly focusing on England and France. The book is divided into two parts: Judicial Culture and Punishment.

Part I discusses the Russian judicial system that was centralized into two jurisdictions: the 
courts of the tsar and the church. The criminal sphere was not defined, and Russian legal corpus was strictly utilitarian (p. 28). The reader will find here much about the structure of the judiciary, scribes and executioners, custody and prisons, trials and procedures, and particularly plenty about the corruption and torture; the latter, the author concludes, was used more frequently than in Europe (ch. 6).

It was only in the early eighteenth century that Peter the Great undertook the judicial reforms, which for the first time separated judicial functions from the administrative, replaced the governors holding courts with the appointed judges, and introduced the new court format, language and handwriting. But the separation of powers did not work in early modern Russia, as the courts continued to rely on the governors' support in staffing the personnel and enforcing the law. By the late 1720s, Peter's judicial reforms unraveled, and Russia would have to wait until the 1860 s to acquire a modern independent judicial system (ch. 8).

Part II discusses different forms of punishment: capital and corporal, the exile, and 
specific punishments for specific crimes (witchcraft, heresy, riot, treason, etc.). Kollmann argues that with the adoption of 1649 Law Code, Russia becomes an early modern "police state" ( $p$. 229). Against the background of the expanding Russian state, the Law Code embraced harsher penalties and increasingly resorted to corporal punishment, such as knouting, bastinados, bodily mutilation, and branding. (ch. 10). Witches and heretics were burned, as they were in Europe. By adopting the Military Articles in 1715, Peter I introduced new forms of corporal and capital punishment. In the following years, torture remained in wide use, corporal punishment increased, and executions were carried out promptly. At the same time, the use of capital punishment, which emerged in Russia later than in Western European law, declined for reasons that remain unclear.

Kollmann concludes that the Russian combination of the centralized power and flexible strategies fits the pattern of practices in other early modern societies. But because of the state's overwhelming control of the society, Russia was able to centralize more efficiently than its European 
counterparts (pp. 416-17). In short, the author clams, Russia was no despotism and not a place of vigilante justice and uncontrolled brutality.

But if Russia was no despotism, which country in the early modern Eurasia was? By this standard, the rule of every major sovereign power, from England to China, relied on written laws and the bureaucratic and social means to enforce them. Only in this, very broad sense Russia was similar to its neighbors.

This is a remarkably well researched, thorough, and informative book. So, it is all the more striking that in her attempt to prove that Russia was similar to the West, Kollmann's claim is often strangely at odds with her own data and statements. The author argues against the stereotype of Russia as an inordinately violent place (p. 419) only to confirm on the next page that Russia was "a very violent society." Whether this violence is perpetrated by the state authorities, delegated to specific social groups (landlords vis-a-vis the serfs), or takes place outside of the state control, does not change the matter.

Kollmann observes that the Russians did not absorb the Roman law (p. 424), had no notaries or 
lawyers until the Great Reforms (pp. 48-50) and that "Russia never developed a robust civil service professional elite," (p. 199), all the while maintaining that Russia was not different from the West.

It is, in fact the major differences that are most conspicuous to this reviewer. The Russian law made no distinction between different kinds of laws, above all between the criminal and civil law. Perhaps most significantly, in contrast to the highly developed jurisprudence of the Christian West and Islamic East, early modern Russia lacked the most elementary legal culture. There were no schools or universities to teach law, no legal minds to interpret and debate it, and no lawyers to practice it (to suggest that the square scribes, who at best could be considered as notaries, were similar to the lawyers in the West requires quite a leap of imagination (p. 65).

Moreover, in contrast to a highly complex legal landscape of Europe or Ottoman empire, Russian law did not include any judicial autonomies (there was no Magdeburg law for the towns, for example, or an equivalent of the Ottoman millet system). Neither did it attempt to address the legal issues 
concerning the "colonial peoples," i.e., numerous non-Christian peoples found within Russia's rapidly expanding borders. After all, by the midseventeenth century Russia, when Russia became a multi-religious and multi-ethnic empire, the question of how to resolve the legal conflicts between the Russians and non-Russians was not an idle one. This issue received little attention in the book.

Until the Great Reforms of the 1860s, Russia's judicial system rested on a class of scribes, undersecretaries, and secretaries, whose number was growing exponentially (pp. 48-50). In early modern Russia, law was purely instrumental serving the needs of autocracy and the highly centralized state it represented.

Nancy Kollmann's produced a definitive study of Russian criminal law and its practices. Like her previous books, this too will remain an invaluable source for anyone interested in the legal and social history of early modern Russia.

Michael Khodarkovsky

Loyola University Chicago

mkhodar@luc.edu 
